\title{
Unmasking the Effects of L-DOPA on Rapid Dopamine Signaling with an Improved Approach for Nafion Coating Carbon-Fiber Microelectrodes
}

\author{
Lingjiao Qi, Elina Thomas, Stephanie H. White, Samantha K. Smith, Christie A. Lee, Leslie \\ R. Wilson, and Leslie A. Sombers \\ Department of Chemistry, North Carolina State University, Raleigh, North Carolina 27695, United \\ States
}

\begin{abstract}
L-DOPA has been the gold standard for symptomatic treatment of Parkinson's disease. However, its efficacy wanes over time as motor complications develop. Very little is known about how LDOPA therapy affects the dynamics of fluctuating dopamine concentrations in the striatum on a rapid timescale (seconds). Electrochemical studies investigating the effects of L-DOPA treatment on electrically evoked dopamine release have reported conflicting results with significant variability. We hypothesize that the uncertainty in the electrochemical data is largely due to electrode fouling caused by polymerization of L-DOPA and endogenous catecholamines on the electrode surface. Thus, we have systematically optimized the procedure for fabricating cylindrical, Nafion-coated, carbon-fiber microelectrodes. This has enabled rapid and reliable detection of L-DOPA's effects on striatal dopamine signaling in intact rat brain using fast-scan cyclic voltammetry. An acute dose of $5 \mathrm{mg} / \mathrm{kg}$ L-DOPA had no significant effect on dopamine dynamics, demonstrating the highly efficient regulatory mechanisms at work in the intact brain. In contrast, administration of $200 \mathrm{mg} / \mathrm{kg}$ L-DOPA significantly increased the amplitude of evoked dopamine release by $\sim 200 \%$. Overall, this work describes a reliable tool that allows a better measure of L-DOPA augmented dopamine release in vivo, measured using fast-scan cyclic voltammetry. It provides a methodology that improves the stability and performance of the carbon fiber microelectrode when studying the molecular mechanisms underlying L-DOPA therapy, and also promises to benefit a wide variety of studies because Nafion is so commonly used in electroanalytical chemistry.
\end{abstract}

\section{Graphical Abstract}

*CORRESPONDING AUTHOR lasomber@ncsu.edu. ASSOCIATED CONTENT

Supplemental Figure S1. This material is available free of charge via the Internet at http://pubs.acs.org. 


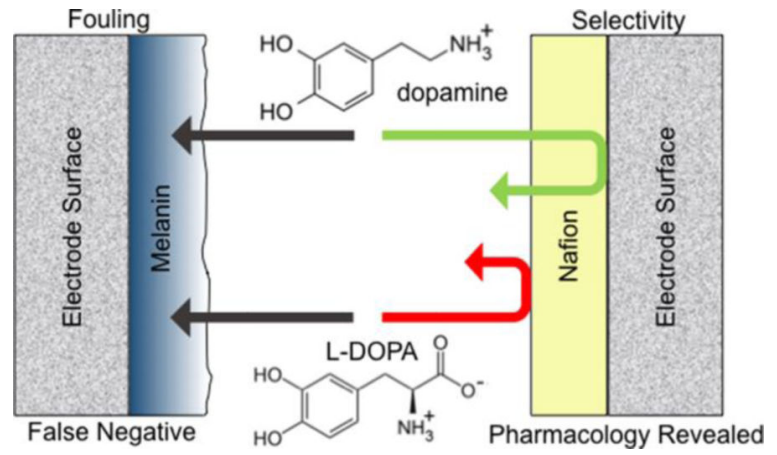

\section{Keywords}

fast-scan cyclic voltammetry; in vivo; electrode fouling; Parkinson's disease; ascorbic acid

\section{INTRODUCTION}

Parkinson's disease (PD) is a neurodegenerative disorder that affects more than a million people in the United States ${ }^{1}$. It is characterized by motor deficits including bradykinesia, rigidity, and resting tremor, resulting from a progressive loss of nigrostriatal dopamine (DA) neurons ${ }^{2,3}$. DA does not readily cross the blood-brain barrier, thus its use for treating the symptoms of PD is precluded ${ }^{4}$. 3, 4-dihydroxyphenyl-L-alanine (L-DOPA), the metabolic precursor to DA, has routinely been used for symptomatic treatment of PD since the late $1960 \mathrm{~s}^{3,5,6}$. However, the efficacy of prolonged L-DOPA treatment wanes over time and patients develop serious motor complications ${ }^{3,7,8}$. Despite common use in the therapeutic management of PD, remarkably little is known about how L-DOPA replacement therapy alters the dynamics of pulsatile DA fluctuations that occur on a fast (seconds) timescale.

The vast majority of studies that have investigated these questions have analyzed dialysate collected in the striatum ${ }^{9-12}$. Microdialysis is a diffusion-based sampling method that is well suited to examine steady state or slowly changing levels of analytes in the extracellular fluid ${ }^{13}$. Thus, these studies have significantly advanced our knowledge on how L-DOPA serves to gradually increase striatal DA levels ${ }^{9-12}$. However, quantification of the effects of L-DOPA on rapid DA dynamics is also important, because patients with Parkinson's disease are impaired in cognitive tasks that require learning from positive (and negative) feedback ${ }^{14,15}$, and rapid DA signaling in both the sensorimotor and limbic corticostriatal circuits has been shown to play a key role in reinforcement learning processes ${ }^{16-20}$. Over the past twenty years, electrochemical techniques have proven to be particularly useful for monitoring rapid changes in DA concentration resulting from discrete neurochemical events, and voltammetric studies have provided fundamental information to describe how rapid DA fluctuations underlie discrete aspects of motivated behavior in animal subjects. For example, phasic dopamine release in the nucleus accumbens core has been shown to correlate with the presentation of Pavlovian reward-predictive cues and to precede the initiation of rewardseeking actions ${ }^{19}$. However, few electrochemical studies have investigated the effects of LDOPA administration on phasic DA fluctuations in the dorsal striatum (but see Phillips et al. ${ }^{21}$ ), and measurements of the effects of L-DOPA on electrically evoked DA release have 
reported conflicting results with significant variability ${ }^{22-25}$. Clarifying this question is critical to developing improved therapies for the treatment of PD.

We hypothesize that much of the uncertainty in the electrochemical data is due to complications associated with the chemical nature of L-DOPA and DA. Both species selfpolymerize in a mechanism that likely involves oxidation of the catechol to a quinone ${ }^{26}$. Near neutral $\mathrm{pH}$, the amine group inherent to dopamine-o-quinone (o-DQ) can serve as a nucleophile, initiating an intramolecular cyclization to generate leucodopachrome (LDC) ${ }^{27}$. Further oxidation generates dopachrome (DC), which may polymerize to melanin by a free radical polymerization ${ }^{28}$ (Scheme 1). The oxidative cross-linking generates robust water resistant bonds that enable the formation of thin, surface-adherent films on a wide range of materials, including the surface of electrodes ${ }^{29-31}$. This film reduces the active surface area of the sensor and attenuates sensitivity ${ }^{32-34}$.

Nafion, a perfluorinated ion-exchange polymer, has been extensively used on the surface of sensors to repel interfering and adsorbing species ${ }^{35-37}$. There are numerous protocols for creating a Nafion membrane at the electrode surface ${ }^{35,38-46}$; however, a reliable means for consistent generation of a simple Nafion membrane on cylindrical carbon-fiber microelectrodes has not yet been achieved (but see Heien et al. ${ }^{46}$ for description of a robust Nafion/polyethylenedioxythiophene composite membrane). Electrochemical data collected using Nafion-coated electrodes can be highly variable, presumably due to inconsistent adhesion of the Nafion (both hydrophobic and hydrophilic regions) with the electrode surface $^{45}$. Reliable generation of a membrane is confounded by the fact that the morphology of Nafion is very sensitive to the nature of the solvent in which it is dissolved ${ }^{43}$. The problem is exacerbated at carbon-fiber microelectrodes, as electrochemical conditioning changes the chemical functionalities inherent to the carbon surface ${ }^{47}$, even etching the surface when electrodes are rapidly scanned to anodic limits of $\sim 1.3 \mathrm{~V}{ }^{48}$. By refining the parameters by which a Nafion coating is applied to the electrode, we have advanced a technique for generating a carbon fiber microelectrode that is less sensitive to fouling by polymerization of L-DOPA or dopamine at the surface. We use fast-scan cyclic voltammetry (FSCV) to demonstrate that generation of a Nafion membrane after electrochemical conditioning reliably produces a uniform film on the sensor surface that preserves a rapid response to DA while preventing fouling. We then use this approach to assess the effects of various concentrations of systemic L-DOPA administration on DA dynamics measured in rat striatum with sub-second temporal resolution. In addition to providing chemical information that is highly relevant to the most common therapy used in the treatment of PD, this work serves to benefit a wide variety of studies plagued by electrode fouling because Nafion is so commonly used in electroanalytical chemistry.

\section{EXPERIMENTAL SECTION}

\section{Chemicals}

All chemicals were purchased from Sigma-Aldrich (St. Louis, MO) and used as received, unless otherwise noted. Solutions were prepared using doubly distilled deionized water (Milli-Q Millipore, Billerica, MA). In vitro characterization of electrode response to DA and ascorbic acid (AA) was conducted in phosphate buffered saline (PBS: $140 \mathrm{mM} \mathrm{NaCl}, 3 \mathrm{mM}$ 
$\mathrm{KCl}, 10 \mathrm{mM} \mathrm{NaH} 2 \mathrm{PO}_{4}$ ) at $\mathrm{pH}$ 7.40. Calibration of electrodes was accomplished in Tris buffer (15 mM Trisma $\mathrm{HCl}, 3.25 \mathrm{mM} \mathrm{KCl}, 1.2 \mathrm{mM} \mathrm{CaCl}_{2}, 1.2 \mathrm{MgCl}_{2}, 2.0 \mathrm{mM} \mathrm{Na}_{2} \mathrm{SO}_{4}$, $1.25 \mathrm{mM} \mathrm{NaH}_{2} \mathrm{PO}_{4}$, and $\left.145 \mathrm{nM} \mathrm{NaCl}\right)$ at $\mathrm{pH} 7.40$.

\section{Carbon-fiber Microelectrode Fabrication}

Carbon-fiber microelectrodes were fabricated as described previously ${ }^{49}$. Briefly, a single T-650 carbon fiber ( $7 \mu \mathrm{m}$ diameter, Cytec Industries, West Patterson, NJ) was aspirated into a glass capillary tube $(0.60 \mathrm{~mm}$ external diameter and $0.40 \mathrm{~mm}$ internal diameter, A-M Systems, Carlsburg, WA) and heat pulled with a micropipette puller (Narishige, Tokyo, Japan) to taper the glass to form two sealed microelectrodes. The carbon fiber extending beyond the glass seal was cut to approximately $100 \mu \mathrm{m}$ under an optical microscope. A stainless steel lead with conductive silver paint (GC Electronics, Rockford, IL) was inserted into the capillary for electrical contact.

\section{Data Acquisition}

All in vitro data were collected in a custom-built flow injection apparatus housed within a Faraday cage. A syringe pump (New Era Pump Systems, Inc., Wantagh, NY) supplied a continuous buffer flow of $1 \mathrm{~mL} / \mathrm{min}$ across both the working and reference electrode. Twosecond bolus injections of analyte were accomplished using a six-port HPLC valve and air actuator controlled by a digital valve interface (Valco Instruments Co., Inc., Houston, TX). All electrodes were conditioned prior to data collection by applying a triangular cyclic waveform $(-0.4 \mathrm{~V}$ to $+1.4 \mathrm{~V}$ versus $\mathrm{Ag} / \mathrm{AgCl})$ with a resting potential of $-0.4 \mathrm{~V}$ at a scan rate of $400 \mathrm{~V} \cdot \mathrm{s}^{-1}$ and at a frequency of $60 \mathrm{~Hz}$ for $\sim 15$ minutes, followed by another 15 minutes of conditioning at $10 \mathrm{~Hz}$. In some instances, this conditioning occurred after Nafion electrodeposition. Electrochemical measurements used the same waveform applied at a frequency of $10 \mathrm{~Hz}$, as described previously ${ }^{50}$. Commercially available TH-1 software (ESA, Chelmsford, MA) was used with a DAC/ADC card (6251, National Instruments, Austin, TX), for waveform generation and data collection. A second National Instruments card (6711) was used for synchronization of waveform, data collection, and electrical stimulation. Signal processing (background subtraction, signal averaging, and digital filtering) was software-controlled.

\section{Nafion-Coating Protocols}

Prior to use, all bare carbon-fiber microelectrodes were soaked in filtered isopropyl alcohol purified with Norit A® activated carbon (MP Biomedicals, LLC, Solon, OH) for at least 30 min to remove surface impurities ${ }^{51}$. Two different protocols were used to create the Nafion membrane: dip coating and electrodeposition. For the dip-coating procedure, the tip of the microelectrode was immersed in the Nafion solution (DE520, Ion Power, DE) for $5 \mathrm{~min}$, allowed to air dry for $10-15 \mathrm{~s}$, and then dried in an oven for $10 \mathrm{~min}$ at $70^{\circ} \mathrm{C}$. For electrodeposition, the carbon-fiber microelectrode tip was lowered into the Nafion solution and a continuous potential $(+0.5,+1.0$, or $+1.5 \mathrm{~V}$ vs. $\mathrm{Ag} / \mathrm{AgCl})$ was applied for 30,60 , or 90 $\mathrm{s}$ with a DC power supply (3B Scientific, Tucker, GA) to generate the Nafion layer. The electrodes were then allowed to air dry for 10-15 s, and subsequently dried in an oven for 10 $\min$ at $70^{\circ} \mathrm{C}$. All electrodes were stored at room temperature. Prior to Nafion coating, some carbon-fiber microelectrodes were electrochemically conditioned with a triangular 
waveform ( $-0.4 \mathrm{~V}$ to $1.4 \mathrm{~V}$ vs. $\mathrm{Ag} / \mathrm{AgCl}, 400 \mathrm{~V} / \mathrm{s})$ applied at a frequency of $60 \mathrm{~Hz}$ for 10 min, and subsequently at a frequency of $10 \mathrm{~Hz}$ for an additional $5 \mathrm{~min}$.

\section{Surgery}

Surgical procedures were performed as described previously ${ }^{52}$. Briefly, adult male SpragueDawley rats weighing 250-300 g were purchased from Charles River Laboratories

(Wilmington, MA). Rats were deeply anaesthetized with an intraperitoneal (i.p.) injection of sodium urethane $(3 \mathrm{~g} / \mathrm{kg}$ ) and positioned in a stereotaxic frame (Kopf Instrumentation;

Tujunga, CA). A heating pad (Harvard Apparatus, Holliston, MA) was used to maintain body temperature at $37^{\circ} \mathrm{C}$. Holes for electrodes were drilled in the skull according to coordinates from the brain atlas of Paxinos and Watson ${ }^{53}$. Working electrodes were placed in caudate-putamen $(\mathrm{CPu},+1.2 \mathrm{~mm}$ anterior-posterior and $+2.0 \mathrm{~mm}$ medial-lateral relative to bregma, $-4.5 \mathrm{~mm}$ dorsal-ventral from the skull surface). The $\mathrm{Ag} / \mathrm{AgCl}$ reference electrode was placed contralateral to the working electrode. The bipolar stimulating electrode (Plastics One, Roanoke, VA) was placed above the medial forebrain bundle (MFB, $-4.6 \mathrm{~mm}$ anteriorposterior and $+1.3 \mathrm{~mm}$ medial-lateral to bregma, $-8.5 \mathrm{~mm}$ dorsal-ventral from the skull surface). Biphasic stimulation pulses ( $60 \mathrm{~Hz}, 24$ pulses, $150 \mu \mathrm{A}, 2 \mathrm{~ms}$ per phase) were delivered to the MFB every 5 min to evoke DA release in the terminal region of the $\mathrm{CPu}$. The working electrode was cycled as it was lowered into tissue, and the positions of the working and stimulating electrodes were optimized to maximize electrically evoked DA signaling. All experimental procedures were approved by the Institutional Animal Care and Use Committee at the North Carolina State University.

\section{In-Vivo Experimental Design}

Following electrode implantation, carbon-fiber microelectrodes were cycled at $10 \mathrm{~Hz}$ for 15 min to stabilize the background current. L-DOPA methyl-ester and benserazidehydrochloride, a peripheral DOPA decarboxylase inhibitor ${ }^{54}$, were dissolved together in physiological saline. After baseline data collection, each animal received an acute treatment with L-DOPA methyl-ester/benserazide cocktail at a clinically relevant dose $(6 \mathrm{mg} / \mathrm{kg}+10$ $\mathrm{mg} / \mathrm{kg}$ benserazide, i.p. $)^{25,55}$, followed by a higher dose $(250 \mathrm{mg} / \mathrm{kg}+400 \mathrm{mg} / \mathrm{kg}$ benserazide, i.p.). These doses of L-DOPA methyl-ester are equivalent to $5 \mathrm{mg} / \mathrm{kg}$ and 200 $\mathrm{mg} / \mathrm{kg}$ of L-DOPA, respectively ${ }^{25}$. Data was collected for one hour after each drug administration.

\section{Statistics}

All data are presented as the mean \pm standard error of the mean (SEM), unless otherwise noted. Statistical and graphical analyses were carried out using GraphPad Prism 5 (GraphPad Software, Inc., La Jolla, CA) or SPSS (IBM SPSS Statistics Software v. 17.0, Armonk, NY). The Student's t-test was used to compare two groups. One-way analysis of variance (ANOVA) with paired samples t-test was used for post hoc determination of statistical differences between three or more groups across a single independent variable. When two classes of variables were compared, two-way ANOVA was applied with independent t-tests. Significance was designated at $\mathrm{p}<0.05$. 


\section{RESULTS AND DISCUSSION}

\section{The Effects of L-DOPA on Electrically Evoked Dopamine Release}

DA is normally synthesized from tyrosine in a two-step process. First, a hydroxyl group is attached to tyrosine by the enzyme tyrosine hydroxylase (TH), using oxygen, tetrahydrobiopterin, and $\mathrm{Fe}^{2+}$ as cofactors to produce L-DOPA ${ }^{56}$. L-DOPA is then efficiently converted to DA by the enzyme L-amino acid decarboxylase (AADC), using pyridoxal phosphate as a cofactor. There are several physiological mechanisms by which exogenous LDOPA can affect presynaptic DA release (for review see ${ }^{57}$ ). Studies using single cells have demonstrated that L-DOPA is effectively loaded into the neuronal cytosol by the L-amino acid transporter ${ }^{58}$. In primary cultures of murine substantia nigra neurons, L-DOPA treatment increases DA levels in the cytosol by $>100$-fold ${ }^{59,60}$. The DA is loaded into vesicles by the vesicular monoamine transporter (VMAT2). Amperometric recordings from these cells have demonstrated that the number of DA molecules released in single synaptic vesicle fusion events (termed quantal size) is increased from $\sim 3,000$ to $~ 10,000$ DA molecules $(-300 \%)$ in only 30 minutes ${ }^{61,62}$. A similar increase in quantal size occurs in PC12 cells, and electron micrographs have shown that L-DOPA treatment also serves to increase the volume of individual dense core vesicles in these cells, in order to accommodate the additional $\mathrm{DA}^{63,64}$. However, in healthy brain tissue L-DOPA treatment could decrease evoked dopamine release by D2-mediated autoinhibition of DA release ${ }^{65}$. Additionally, the principal enzymes involved in DA synthesis, TH and AADC, are both regulated by DA autoreceptor-mediated second-messenger systems, such that DA synthesis is decreased when extracellular DA concentrations are increased ${ }^{66-68}$.

Initial experiments assessed the effects of L-DOPA administration on real-time striatal DA dynamics using bare carbon-fiber microelectrodes in intact Sprague-Dawley rats.

Representative color plots, each containing 150 background-subtracted voltammograms, are shown in Figure 1A. These plots provide a representation of all changes in current collected across the entire potential window, enabling discrimination of specific electroactive species as they fluctuate over time ${ }^{69}$. The left column shows DA dynamics elicited in response to electrical stimulation of the MFB (arrow) prior to any pharmacological manipulation. A current versus time trace extracted at the oxidation potential of DA $(\sim 0.6 \mathrm{~V})$, and converted to concentration following post-calibration of the electrode, is shown in the middle of each panel. A cyclic voltammogram that serves to identify DA is also shown (lower panel). In this representative example, electrical stimulation elicited the release of $595 \mathrm{nM}$ DA in the vicinity of the carbon-fiber recording electrode positioned in the dorsal striatum. Electrically-evoked DA release appeared to decrease to $482 \mathrm{nM}$ after administration of LDOPA ( $5 \mathrm{mg} / \mathrm{kg}$, i.p. middle), and to decrease even further (to $292 \mathrm{nM}$ ) after a higher dose (200 mg/kg i.p. right) was administered. By contrast, administration of an identical volume of saline (vehicle control) did not have any significant effect on the evoked DA signal (Figure S1). Figure 1B summarizes the entire data set $(n=5$ animals) by plotting the concentration of electrically evoked DA release measured after administration of L-DOPA as a percentage of the baseline DA concentration. Twenty-five minutes after L-DOPA (5 $\mathrm{mg} / \mathrm{kg}$, orange arrow), electrically evoked DA release was significantly decreased from 529 $\pm 19 \mathrm{nM}$ to $428 \pm 24 \mathrm{nM}\left({ }^{*} \mathrm{p}<0.05\right)$. This DA signal was further decreased to $362 \pm 54 \mathrm{nM}$ 
after $50 \mathrm{~min}$. Subsequent administration of L-DOPA at a higher dose (200 $\mathrm{mg} / \mathrm{kg}$, red arrow) further decreased the amplitude of electrically evoked DA to $~ 45 \%$ of baseline $(207 \pm 33$ $\mathrm{nM}, * * * \mathrm{p}<0.001)$. However, it is important to note that large increases in extracellular LDOPA are observed in the brain after systemic L-DOPA administration using microdialysis ${ }^{70-72}$, and polymerization of L-DOPA could foul the electrode, counfounding interpretation of the results.

\section{Microelectrode Fouling by L-DOPA}

Background subtracted FSCV is a differential measurement that measures rapid changes in electroactive analytes at the electrode surface. As such, basal levels of DA and L-DOPA in brain tissue are not detected, even if high concentrations of these analytes are present. However, the catechol moiety inherent to both DA and L-DOPA is easily oxidized to the reactive o-quinone by the potentials used in this study $13,73,74$, and both molecules can also be enzymatically oxidized in the brain. As described above, the oxidized form can then immediately undergo a series of complex chemical polymerization reactions to produce melanin ${ }^{75-79}$. To investigate if the decrease in electrically evoked DA release measured at the bare carbon-fiber electrodes following L-DOPA administration (Figure 1) could be attributed to fouling, electrode sensitivity to $1 \mu \mathrm{M}$ DA was assessed in vitro. Sensitivity was not compromised following exposure to $1 \mu \mathrm{M} \mathrm{L}$-DOPA (Figure 2A); however, exposure to $50 \mu \mathrm{M}$ L-DOPA significantly attenuated sensitivity to DA (Figure $2 \mathrm{~B}, \mathrm{n}=6, * * * \mathrm{p}<0.001$ ). Indeed, Hefti et al. have reported a peak value of $\sim 100 \mu \mathrm{M} \mathrm{L-DOPA}(20 \mu \mathrm{g} / \mathrm{g})$ in the rat striatum after administration of a very high dose of L-DOPA $(500 \mathrm{mg} / \mathrm{kg}){ }^{80}$. Thus, the decrease in evoked DA detected at bare carbon-fiber microelectrodes after a $200 \mathrm{mg} / \mathrm{kg} \mathrm{L}$ DOPA treatment suggests fouling of the electrode surface. If not taken into account, this significantly skews interpretation and quantification of in vivo data.

\section{Systematic Characterization of Nafion-Coating Procedure}

Nafion is a cation-exchange polymer. Thus, when coated on the carbon-fiber electrode surface it serves to increase sensitivity to positively charged species, such as DA at physiological $\mathrm{pH}^{38-41,43,44}$. It also decreases sensitivity to several negatively-charged species, including AA, which is ubiquitous in the brain ${ }^{38}$. L-DOPA is a zwitterion at physiological $\mathrm{pH}$. It is electrochemically active, with a voltammogram that looks identical to that for DA. Nafion is not effective at excluding L-DOPA when relatively low concentrations $(1 \mu \mathrm{M})$ are investigated. However, Nafion is quite effective at excluding higher concentrations of L-DOPA $(50 \mu \mathrm{M})$. These trends are demonstrated by the representative cyclic voltammograms presented in the upper panel of Figure 3, which were collected in vitro using bare and Nafion-coated carbon-fiber microelectrodes (Nafion electrodeposited at $1.0 \mathrm{~V}$ for $90 \mathrm{~s}$ onto electrochemically pretreated electrodes). The entire data set is summarized in the Table.

The presence of a Nafion layer can be confirmed by reporting a sensitivity ratio for DA (the quotient of the sensitivities measured before and after coating). A large deviation from unity indicates the presence of a robust membrane. Figure 4 presents normalized sensitivity ratios for DA. Electrodes were prepared using a variety of Nafion deposition procedures. The most straightforward protocol is dip coating. With this approach, the electrode surface is covered 
with Nafion by dipping the electrode in the polymer solution and evaporating the solvent $37,38,43,45,81,82$. Alternatively, Nafion can be electrodeposited onto the carbon surface by application of a potential sufficient to generate an anodic current ${ }^{39-41}$. The data demonstrate that coating cylindrical carbon-fiber electrodes by way of electrodeposition is more effective than a simple dip coating procedure. Thus, all subsequent studies presented herein utilized electrodeposition to generate a Nafion membrane.

It is well established that electrochemical pretreatment of the carbon fiber surface can enhance electron transfer kinetics and significantly improve electrochemical performance by shifting the surface chemistry of the sensor to that which is present during use $47,83-87$. Thus, carbon-fiber microelectrodes are commonly conditioned immediately prior to data collection ${ }^{49}$. It has also more recently been established, using various spectroscopic techniques including $\mathrm{X}$-ray photoelectron spectroscopy ${ }^{88}$, thermal desorption mass spectrometry ${ }^{89}$, enzyme-immobilized fluorescence microscopy ${ }^{90,91}$, optical spectroscopy ${ }^{92}$, and Raman spectroscopy ${ }^{47}$, that application of potentials greater than $\sim 1.3 \mathrm{~V}$ can chemically alter, or even etch, the electrode surface $47,48,87$. Thus, we hypothesized that electrochemical conditioning with a commonly used waveform (triangular, ranging from $-0.4 \mathrm{~V}$ to $1.4 \mathrm{~V}$ vs. $\mathrm{Ag} / \mathrm{AgCl}$ ) before membrane deposition would improve adhesion of Nafion to the electrode surface. We quantitatively compared the performance of carbon-fiber microelectrodes that were conditioned before and after Nafion coating with microelectrodes that were electrochemically pre-treated and left bare. The data unequivocally demonstrate that Nafion electrodeposition (by application of $1.0 \mathrm{~V}$ for $30 \mathrm{sec}$ ) was most effective when electrodes were conditioned prior to the deposition procedure (Figure 4B). Based on this, all subsequent protocols included electrochemical pretreatment of bare carbon-fiber microelectrodes prior to electrodeposition of Nafion.

Next, the potentials employed to electrodeposit the Nafion membrane were systematically investigated. Three potentials were selected: $+0.5,+1.0$ and $+1.5 \mathrm{~V}$ vs. $\mathrm{Ag} / \mathrm{AgCl}$, as these have all been previously reported in the literature $41,44,93,94$. The results indicate that +1.0 and $+1.5 \mathrm{~V}$ were more effective than $+0.5 \mathrm{~V}$ in generating a reliable membrane (Figure 4C). However, as described above, the application of positive potentials can modify the surface of the carbon fiber, making it highly adsorptive and potentially slowing electrode response time, convoluting electrochemical performance ${ }^{85,87}$. Thus, $1.0 \mathrm{~V}$ (vs. $\mathrm{Ag} / \mathrm{AgCl}$ ) was selected for the electrodeposition of Nafion.

It is important to note that the Nafion membrane itself presents a diffusion barrier that can reduce electrode response time. To maintain the rapid temporal response required for detection of neurotransmitter fluctuations in vivo, a thin Nafion layer is required. Indeed, previous studies have demonstrated that Nafion membranes can be generated such that electrode response times are not significantly different from uncoated microelectrodes ${ }^{35,} 37$. Figure 4 shows that with our approach, an electrodeposition time of $90 \mathrm{~s}$ produced the best membrane performance in terms of sensitivity (Figure 4D) and stability (Figure 4E). With this approach, electrode performance was stable for at least two hours, presumably because the structural integrity of the Nafion coating (a perfluorosulfonated polymer) is derived from strong interactions between Nafion chains, rather than interactions between the Nafion and the carbon surface. This membrane did not significantly affect the sub-second response time 
of the electrode to a step change in the concentration of DA in a flow injection system (Figure 5A), or to the stimulated secretion of DA in an intact brain (Figure 5B). Finally, Nafion-coated electrodes prepared using different electrodeposition times were tested in vivo. Figure 5C shows representative data collected in the striatum after administration of 5 $\mathrm{mg} / \mathrm{kg}$ (orange arrow) and $200 \mathrm{mg} / \mathrm{kg}$ (red arrow) L-DOPA. These data suggest that the Nafion-coated electrodes prepared using electrodeposition times of $30 \mathrm{~s}$ (blue) and $60 \mathrm{~s}$ (green) did not resist L-DOPA induced fouling as efficiently as the Nafion-coated electrode prepared using an electrodeposition time of $90 \mathrm{~s}$ (brown), which was able to detect a robust increase in electrically-evoked DA release following L-DOPA treatment.

\section{The Effects of L-DOPA on Striatal DA Dynamics}

The optimized Nafion deposition procedure (electrodeposition using $1.0 \mathrm{~V}$ for $90 \mathrm{~s}$ ) was used to investigate the effects of L-DOPA administration on electrically evoked striatal DA release. Representative color plots with corresponding DA concentration traces and cyclic voltammograms are shown in Figure 6. These data demonstrate that DA release increased across the entire data set $(* * * * \mathrm{p}<0.0001$, one-way repeated measures ANOVA). Post-hoc analysis with a paired samples t-test demonstrated that a clinically relevant dose of $5 \mathrm{mg} / \mathrm{kg}$ had no significant effect on electrically-evoked DA release as compared to baseline; however, L-DOPA administered at dose of $200 \mathrm{mg} / \mathrm{kg}$ significantly increased DA release ( 200\%), 25 min after drug administration $(* p<0.05)$. These data suggest that the regulatory mechanisms of intact animals are capable of controlling extracellular DA very efficiently in response to acute administration of a clinically relevant dose of L-DOPA (5 $\mathrm{mg} / \mathrm{kg})$. However, administration of a higher dose of L-DOPA $(200 \mathrm{mg} / \mathrm{kg})$ enhances DA overflow. This finding is consistent with previous studies using microdialysis, which report that striatal DA was increased by $200 \%$ in intact animals following a $200 \mathrm{mg} / \mathrm{kg}$ or higher dose of L-DOPA 10, 24, 95 . Importantly, the data collected using the Nafion-coated electrodes significantly contrast with the data collected using bare electrodes (Figure 1 and re-plotted here in light orange and red). The differences between these data sets (gray bar, ${ }^{++++} \mathrm{p}=$ 0.0001-0.05, repeated measures two-way ANOVA) confirm that a robust Nafion membrane is necessary to quantitatively report the effects of L-DOPA treatment on DA dynamics when using carbon-fiber microelectrodes and high concentrations of L-DOPA.

\section{CONCLUSIONS}

Overall, the data indicate that when systemically treating with high doses of L-DOPA, a carbon-fiber microelectrode implanted in the brain is easily fouled, resulting in decreased sensitivity to DA. This is likely due to the polymerization of catecholamines on the electrode surface. By refining the parameters by which a Nafion coating is applied to the electrode, we have advanced a technique for generating a carbon fiber microelectrode that maintains a rapid electrode response time and is less sensitive to fouling. The improved performance of these electrodes allows a better measure of L-DOPA augmented DA release in vivo when using FSCV. With this approach, an acute dose of $5 \mathrm{mg} / \mathrm{kg} \mathrm{L-DOPA} \mathrm{had} \mathrm{little} \mathrm{effect} \mathrm{on} \mathrm{DA}$ release in healthy striatal tissue, consistent with several reports in the literature that have used microdialysis measurements 10,96 or mathematical modeling ${ }^{57}$ to demonstrate that DA terminals play a crucial role in the clearance of extracellular DA formed from exogenous L- 
DOPA in healthy striatum. In contrast, administration of $200 \mathrm{mg} / \mathrm{kg}$ L-DOPA was capable of significantly increasing evoked DA release.

\section{Supplementary Material}

Refer to Web version on PubMed Central for supplementary material.

\section{Acknowledgments}

We thank Leyda Lugo and Vincent Toups for their help in determination of Nafion membrane thickness, James Roberts for assistance in manuscript preparation, Xiaohu Xie for assistance with statistical data analysis, and Leyda Lugo and Robert Grossfeld for critique of this manuscript and thoughtful discussion. This work was supported by the U.S. National Institutes of Neurological Disorders and Stroke (1R01NS076772-01to L.A.S.).

\section{References}

1. Sutachan JJ, Casas Z, Albarracin SL, Stab BR 2nd, Samudio I, Gonzalez J, Morales L, Barreto GE. Nutr. Neurosci. 2012; 15(3):120-126. [PubMed: 22732354]

2. Jankovic J. J. Neurol. Neurosurg. Psychiatry. 2008; 79(4):368-376. [PubMed: 18344392]

3. Fahn S. J. Neural Transm. Suppl. 2006; (71):1-15. [PubMed: 17447410]

4. Bear, MF.; Connors, BW.; Paradiso, MA. Neuroscience : Exploring the Brain. 3rd. Philadelphia, PA: Lippincott Williams \& Wilkins; 2007.

5. Cotzias GC, Van Woert MH, Schiffer LM. N Engl J Med. 1967; 276(7):374-379. [PubMed: 5334614]

6. Hornykiewicz O. Amino Acids. 2002; 23(1-3):65-70. [PubMed: 12373520]

7. Ahlskog JE, Muenter MD. Movement Disorders. 2001; 16(3):448-458. [PubMed: 11391738]

8. Nutt, JG. Dyskinesia Induced by Levodopa and Dopamine Agonists in Patients with Parkinson's Disease, in Drug-Induced Movement Disorders. Mount Kisko: Futura Publishing Co. Inc; 1992.

9. Lindgren HS, Andersson DR, Lagerkvist S, Nissbrandt H, Cenci MA. J. Neurochem. 2010; 112(6): 1465-1476. [PubMed: 20050978]

10. Abercrombie ED, Bonatz AE, Zigmond MJ. Brain Res. 1990; 525(1):36-44. [PubMed: 2123121]

11. Robinson TE, Mocsary Z, Camp DM, Whishaw IQ. J. Neurosci. 1994; 14(5 Pt 1):2687-2696. [PubMed: 7514209]

12. Zhang WQ, Tilson HA, Nanry KP, Hudson PM, Hong JS, Stachowiak MK. Brain Res. 1988; 461(2):335-342. [PubMed: 3141002]

13. Robinson DL, Hermans A, Seipel AT, Wightman RM. Chem. Rev. 2008; 108(7):2554-2584. [PubMed: 18576692]

14. Frank MJ, Seeberger LC, O’Reilly RC. Science. 2004; 306(5703):1940-1943. [PubMed: 15528409]

15. Frank MJ. J. Cogn. Neurosci. 2005; 17(1):51-72. [PubMed: 15701239]

16. Smith KS, Graybiel AM. J. Neurophysiol. 2016; 115(3):1487-1498. [PubMed: 26740533]

17. Willuhn I, Burgeno LM, Everitt BJ, Phillips PE. Proc. Natl. Acad. Sci. U. S. A. 2012; 109(50): 20703-20708. [PubMed: 23184975]

18. Phillips PE, Stuber GD, Heien ML, Wightman RM, Carelli RM. Nature. 2003; 422(6932):614618. [PubMed: 12687000]

19. Wassum KM, Ostlund SB, Loewinger GC, Maidment NT. Biol. Psychiatry. 2013; 73(8):747-755. [PubMed: 23374641]

20. Saddoris MP, Sugam JA, Stuber GD, Witten IB, Deisseroth K, Carelli RM. Biol. Psychiatry. 2015; 77(10):903-911. [PubMed: 25541492]

21. Willuhn I, Burgeno LM, Groblewski PA, Phillips PE. Nat. Neurosci. 2014; 17(5):704-709. [PubMed: 24705184]

22. May LJ, Kuhr WG, Wightman RM. J. Neurochem. 1988; 51(4):1060-1069. [PubMed: 2971098] 
23. Garris PA, Ciolkowski EL, Pastore P, Wightman RM. J. Neurosci. 1994; 14(10):6084-6093. [PubMed: 7931564]

24. Rodriguez M, Morales I, Gonzalez-Mora JL, Gomez I, Sabate M, Dopico JG, Rodriguez-Oroz MC, Obeso JA. Synapse. 2007; 61(2):61-71. [PubMed: 17117421]

25. Lundblad M, af Bjerken S, Cenci MA, Pomerleau F, Gerhardt GA, Stromberg I. J. Neurochem. 2009; 108(4):998-1008. [PubMed: 19196428]

26. Yu ME, Hwang JY, Deming TJ. Journal of the American Chemical Society. 1999; 121(24):58255826.

27. Tse DC, McCreery RL, Adams RN. J Med Chem. 1976; 19(1):37-40. [PubMed: 1246050]

28. Harreither W, Trouillon R, Poulin P, Neri W, Ewing AG, Safina G. Anal Chem. 2013; 85(15): 7447-7453. [PubMed: 23789970]

29. Lee H, Dellatore SM, Miller WM, Messersmith PB. Science. 2007; 318(5849):426-430. [PubMed: 17947576]

30. Azari S, Zou LD. Journal of Membrane Science. 2012; 401:68-75.

31. Xi ZY, Xu YY, Zhu LP, Wang Y, Zhu BK. Journal of Membrane Science. 2009; 327(1-2):244-253.

32. Koile RC, Johnson DC. Analytical Chemistry. 1979; 51(6):741-744.

33. Adams, RNMC. Electrochemical Detection Methods for Monoamine Measurements in Vitro and in Vivo. Plenum Press; 1982.

34. Stamford JA. J Neurosci Methods. 1986; 17(1):1-29. [PubMed: 3528683]

35. Cahill PS, Walker QD, Finnegan JM, Mickelson GE, Travis ER, Wightman RM. Anal. Chem. 1996; 68(18):3180-3186. [PubMed: 8797378]

36. Burmeister JJ, Pomerleau F, Huettl P, Gash CR, Werner CE, Bruno JP, Gerhardt GA. Biosens Bioelectron. 2008; 23(9):1382-1389. [PubMed: 18243683]

37. Kristensen EW, Kuhr WG, Wightman RM. Anal. Chem. 1987; 59(14):1752-1757. [PubMed: 3631500]

38. Gerhardt GA, Oke AF, Nagy G, Moghaddam B, Adams RN. Brain Res. 1984; 290(2):390-395. [PubMed: 6692152]

39. Rice ME, Oke AF, Bradberry CW, Adams RN. Brain Res. 1985; 340(1):151-155. [PubMed: 4027641]

40. Singh YS, Sawarynski LE, Dabiri PD, Choi WR, Andrews AM. Anal. Chem. 2011; 83(17):66586666. [PubMed: 21770471]

41. Hashemi P, Dankoski EC, Petrovic J, Keithley RB, Wightman RM. Anal. Chem. 2009; 81(22): 9462-9471. [PubMed: 19827792]

42. Valdes TI, Moussy F. Diabetes Technol Ther. 2000; 2(3):367-376. [PubMed: 11467339]

43. Mauritz KA, Moore RB. Chem Rev. 2004; 104(10):4535-4585. [PubMed: 15669162]

44. Capella P, Ghasemzadeh B, Mitchell K, Adams RN. Electroanalysis. 1990; 2(3):175-182.

45. Ross AE, Venton BJ. Analyst. 2012; 137(13):3045-3051. [PubMed: 22606688]

46. Vreeland RF, Atcherley CW, Russell WS, Xie JY, Lu D, Laude ND, Porreca F, Heien ML. Anal. Chem. 2015; 87(5):2600-2607. [PubMed: 25692657]

47. Roberts JG, Moody BP, McCarty GS, Sombers LA. Langmuir. 2010; 26:9116-9122. [PubMed: 20166750]

48. Takmakov P, Zachek MK, Keithley RB, Walsh PL, Donley C, McCarty GS, Wightman RM. Anal. Chem. 2010; 82(5):2020-2028. [PubMed: 20146453]

49. Roberts JG, Lugo-Morales LZ, Loziuk PL, Sombers LA. Methods Mol. Biol. 2013; 964:275-294. [PubMed: 23296789]

50. Sanford AL, Morton SW, Whitehouse KL, Oara HM, Lugo-Morales LZ, Roberts JG, Sombers LA. Anal. Chem. 2010; 82(12):5205-5210. [PubMed: 20503997]

51. Bath BD, Michael DJ, Trafton BJ, Joseph JD, Runnels PL, Wightman RM. Anal. Chem. 2000; 72(24):5994-6002. [PubMed: 11140768]

52. Dragun AE, Quillo AR, Riley EC, Roberts TL, Hunter AM, Rai SN, Callender GG, Jain D, McMasters KM, Spanos WJ. Int. J. Radiat. Oncol. Biol. Phys. 2013; 85(3):e123-e128. [PubMed: 23195779] 
53. Paxinos, GWC. The Rat Brain in Stereotaxic Coordinates. 2nd. Orlando, FL: Academic Press; 1986.

54. Silva MA, Mattern C, Hacker R, Tomaz C, Huston JP, Schwarting RK. Synapse. 1997; 27(4):294302. [PubMed: 9372552]

55. Lindgren HS, Rylander D, Ohlin KE, Lundblad M, Cenci MA. Behav. Brain Res. 2007; 177(1): 150-159. [PubMed: 17157933]

56. Ramsey AJ, Fitzpatrick PF. Biochemistry. 2000; 39(4):773-778. [PubMed: 10651643]

57. Mosharov EV, Borgkvist A, Sulzer D. Mov. Disord. 2015; 30(1):45-53. [PubMed: 25450307]

58. Vieira-Coelho MA, Soares-Da-Silva P. Am. J. Physiol. 1998; 275(1 Pt 1):C104-C112. [PubMed: 9688840]

59. Mosharov EV, Staal RG, Bove J, Prou D, Hananiya A, Markov D, Poulsen N, Larsen KE, Moore CM, Troyer MD, Edwards RH, Przedborski S, Sulzer D. J. Neurosci. 2006; 26(36):9304-9311. [PubMed: 16957086]

60. Mosharov EV, Larsen KE, Kanter E, Phillips KA, Wilson K, Schmitz Y, Krantz DE, Kobayashi K, Edwards RH, Sulzer D. Neuron. 2009; 62(2):218-229. [PubMed: 19409267]

61. Pothos EN, Davila V, Sulzer D. J. Neurosci. 1998; 18(11):4106-4118. [PubMed: 9592091]

62. Staal RG, Mosharov EV, Sulzer D. Nat. Neurosci. 2004; 7(4):341-346. [PubMed: 14990933]

63. Sombers LA, Maxson MM, Ewing AG. J. Neurochem. 2005; 93(5):1122-1131. [PubMed: 15934933]

64. Colliver TL, Pyott SJ, Achalabun M, Ewing AG. J. Neurosci. 2000; 20(14):5276-5282. [PubMed: 10884311]

65. Schmitz Y, Schmauss C, Sulzer D. J. Neurosci. 2002; 22(18):8002-8009. [PubMed: 12223553]

66. Hadjiconstantinou M, Neff NH. CNS Neurosci Ther. 2008; 14(4):340-351. [PubMed: 19040557]

67. Wolf ME, Roth RH. Ann. N. Y. Acad. Sci. 1990; 604:323-343. [PubMed: 2171398]

68. Lindgren N, Xu ZQ, Herrera-Marschitz M, Haycock J, Hokfelt T, Fisone G. Eur. J. Neurosci. 2001; 13(4):773-780. [PubMed: 11207812]

69. Michael D, Travis ER, Wightman RM. Anal Chem. 1998; 70(17):586A-592A.

70. Golembiowska K, Dziubina A. Brain Research. 2004; 998(2):208-217. [PubMed: 14751592]

71. Marburger A, Sohr R, Reum T, Morgenstern R. Journal of Neuroscience Methods. 2000; 102(2): 127-132. [PubMed: 11040409]

72. Zhang J, Qu FR, Nakatsuka A, Nomura T, Nagai M, Nomoto M. Brain Res. 2003; 993(1-2):54-58. [PubMed: 14642830]

73. Eslami M, Zare HR, Namazian M. J Phys Chem B. 2012; 116(41):12552-12557. [PubMed: 22985067]

74. Aslanoglu M, Kutluay A, Goktas S, Karabulut S. Journal of Chemical Sciences. 2009; 121(2):209_ 215.

75. Cabanes J, Garciacanovas F, Lozano JA, Garciacarmona F. Biochimica Et Biophysica Acta. 1987; 923(2):187-195. [PubMed: 3101741]

76. Robinson GM, Smyth MR. Analyst. 1997; 122(8):797-802.

77. Prota, G. Melanins and Melanogenesis. New York: Academic Press; 1992.

78. Graham DG. Molecular Pharmacology. 1978; 14(4):633-643. [PubMed: 98706]

79. Nicolai M, Goncalves G, Natalio F, Humanes M. Journal of Inorganic Biochemistry. 2011; 105(6): 887-893. [PubMed: 21507323]

80. Hefti F, Melamed E, Wurtman RJ. J. Pharmacol. Exp. Ther. 1981; 217(1):189-197. [PubMed: 7205652]

81. Jackson BP, Dietz SM, Wightman RM. Anal. Chem. 1995; 67(6):1115-1120. [PubMed: 7717525]

82. Pihel K, Walker QD, Wightman RM. Anal. Chem. 1996; 68(13):2084-2089. [PubMed: 9027223]

83. Engstrom RC. Analytical Chemistry. 1982; 54(13):2310-2314.

84. Engstrom RC, Strasser VA. Anal. Chem. 1984; 56(2):136-141.

85. Gonon FG, Fombarlet CM, Buda MJ, Pujol JF. Anal. Chem. 1981; 53(9):1386-1389.

86. Saraceno RA, Ewing AG. Anal. Chem. 1988; 60(19):2016-2020. 
87. Heien M, Phillips PEM, Stuber GD, Seipel AT, Wightman RM. Analyst. 2003; 128(12):14131419. [PubMed: 14737224]

88. Langley LA, Villanueva DE, Fairbrother DH. Chem. Mater. 2006; 18(1):169-178.

89. Fagan DT, Kuwana T. Anal. Chem. 1989; 61(9):1017-1023.

90. Pantano P, Kuhr WG. Anal. Chem. 1993; 65(18):2452-2458. [PubMed: 8238939]

91. Pantano P, Kuhr WG. Anal. Chem. 1991; 63(14):1413-1418. [PubMed: 1928721]

92. Ray KR, McCreery RL. J. Electroanal. Chem. 1999; 469(2):150-158.

93. Rice ME, Nicholson C. Anal. Chem. 1989; 61(17):1805-1810. [PubMed: 2802146]

94. Crespi F, Martin KF, Marsden CA. NeuroScience. 1988; 27(3):885-896. [PubMed: 3252175]

95. Di Monte DA, DeLanney LE, Irwin I, Royland JE, Chan P, Jakowec MW, Langston JW. Brain Res. 1996; 738(1):53-59. [PubMed: 8949927]

96. Miller DW, Abercrombie ED. J. Neurochem. 1999; 72(4):1516-1522. [PubMed: 10098856] 

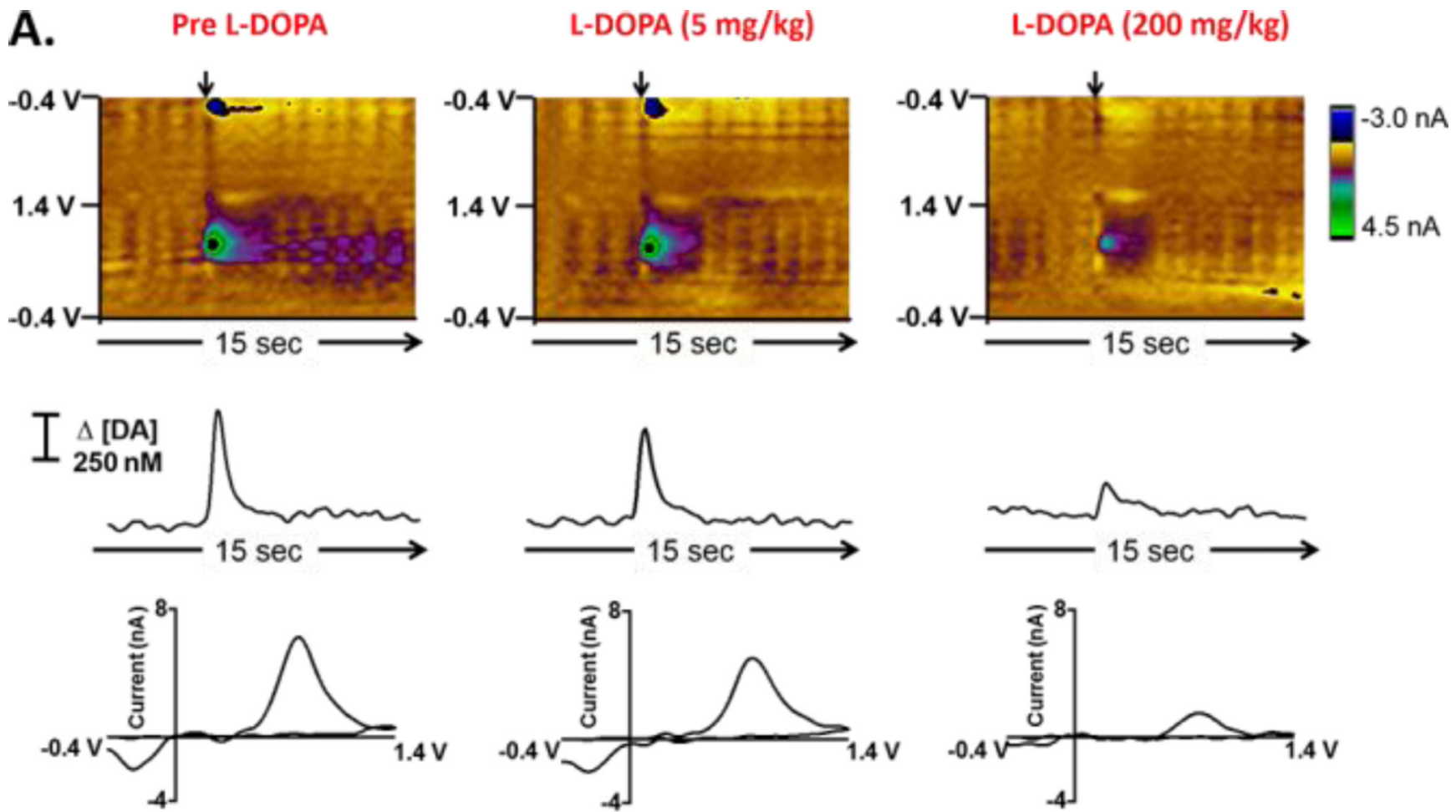

B.

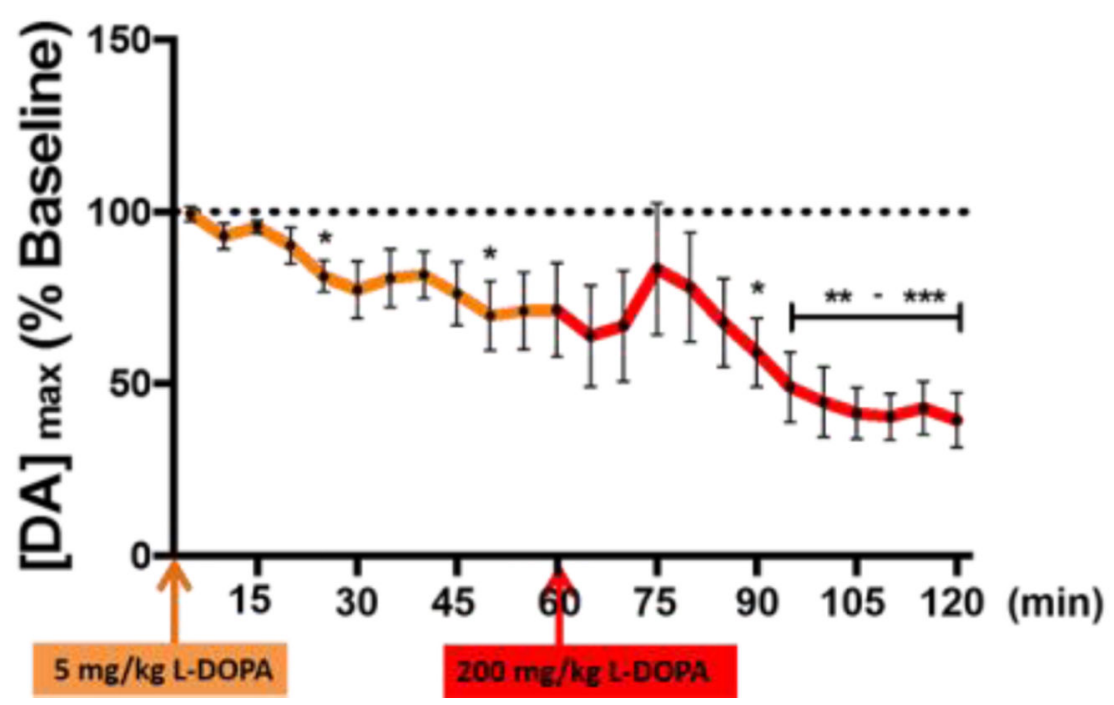

Figure 1.

L-DOPA administration affects electrically evoked DA release recorded at bare carbon-fiber microelectrodes. (A) Representative data collected at a bare carbon-fiber microelectrode before L-DOPA administration (left column), 20 min after administration of L-DOPA (5 $\mathrm{mg} / \mathrm{kg}$, i.p., middle), and $50 \mathrm{~min}$ after administration of a higher dose $(200 \mathrm{mg} / \mathrm{kg}$, i.p., right). Top: Color plots depicting all changes in current (false color) collected over a 15-s window (x-axis) across all potentials (y-axis). Time of electrical stimulation is indicated by the black arrow. Middle: Current vs. time traces extracted at the oxidation potential of DA 
$(+0.6 \mathrm{~V})$. Bottom: Cyclic voltammograms identifying DA. (B) Across the entire data set, there is a significant decrease in electrically evoked DA release upon acute L-DOPA treatment $(\mathrm{n}=5, \mathrm{~F}(23,92)=9.05$, $* * * * \mathrm{p}<0.0001$, one-way repeated measures ANOVA). Post-hoc analysis with a paired samples t-test demonstrated a significant decrease in dopamine release at specific time points $\left(\mathrm{n}=5,{ }^{*} \mathrm{p}<0.05,{ }^{* *} \mathrm{p}<0.01,{ }^{* *} \mathrm{p}<0.001\right)$. 

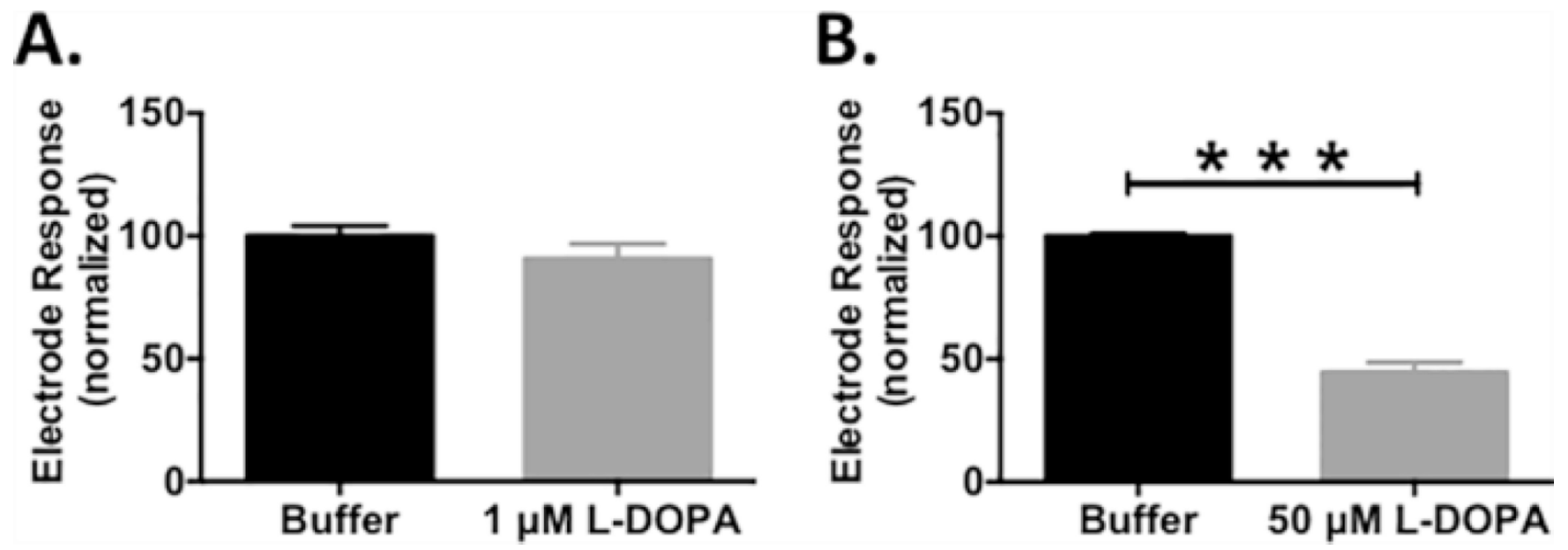

Figure 2.

L-DOPA fouls bare carbon-fiber microelectrodes in vitro. Normalized electrode response to $1 \mu \mathrm{M}$ DA in the absence (black) and presence (grey) of (A) $1 \mu \mathrm{M}$ or (B) $50 \mu \mathrm{M} \mathrm{L-DOPA}$ in the running buffer of the flow-injection apparatus. Sensitivity was significantly attenuated in the presence of $50 \mu \mathrm{M}$ L-DOPA $(\mathrm{n}=6$, paired t- test, $* * * \mathrm{p}<0.001)$. 

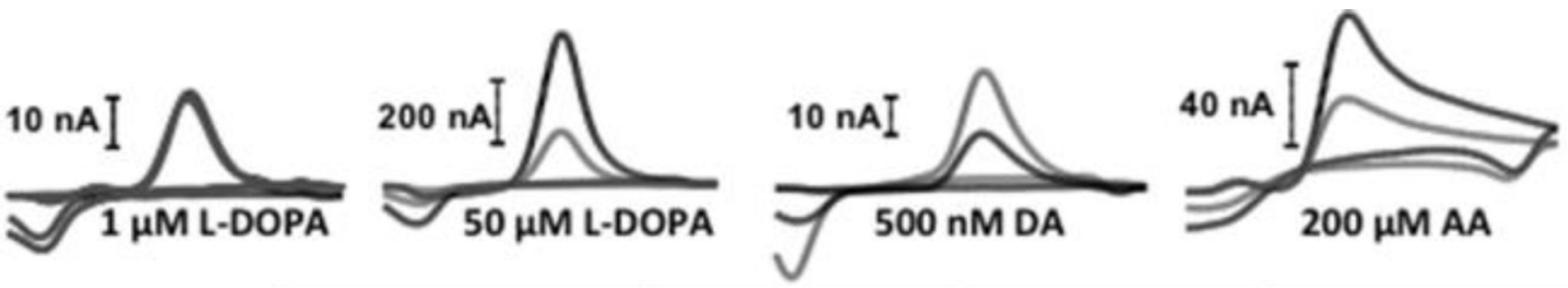

Bare

\section{Analyte}

\section{Bare (nA)}

Coated (nA) \% Difference

Nafion

\begin{tabular}{l|l|l|l}
$1 \mu \mathrm{M}$ L-DOPA & $18.4 \pm 0.4$ & $17.4 \pm 0.5$ & $-5.4 \%$
\end{tabular}

$50 \mu \mathrm{M}$ L-DOPA

500 nM DA

$473 \pm 20$

$131 \pm 3$

$-72.3 \% *$

\section{Figure 3.}

The presence of a Nafion membrane significantly affects sensitivity to L-DOPA, DA, and AA. Upper panel shows representative cyclic voltammograms for bare (black) and Nafioncoated (gray) electrodes for L-DOPA $(1 \mu \mathrm{M})$, DA $(500 \mathrm{nM})$, and AA $(200 \mu \mathrm{M})$. Lower panel: A summary of the entire data set. The values are averages \pm SEM. $(n=3-9$ electrodes per group, unpaired t-test, $* * p<0.01, * \mathrm{p}<0.05)$. 

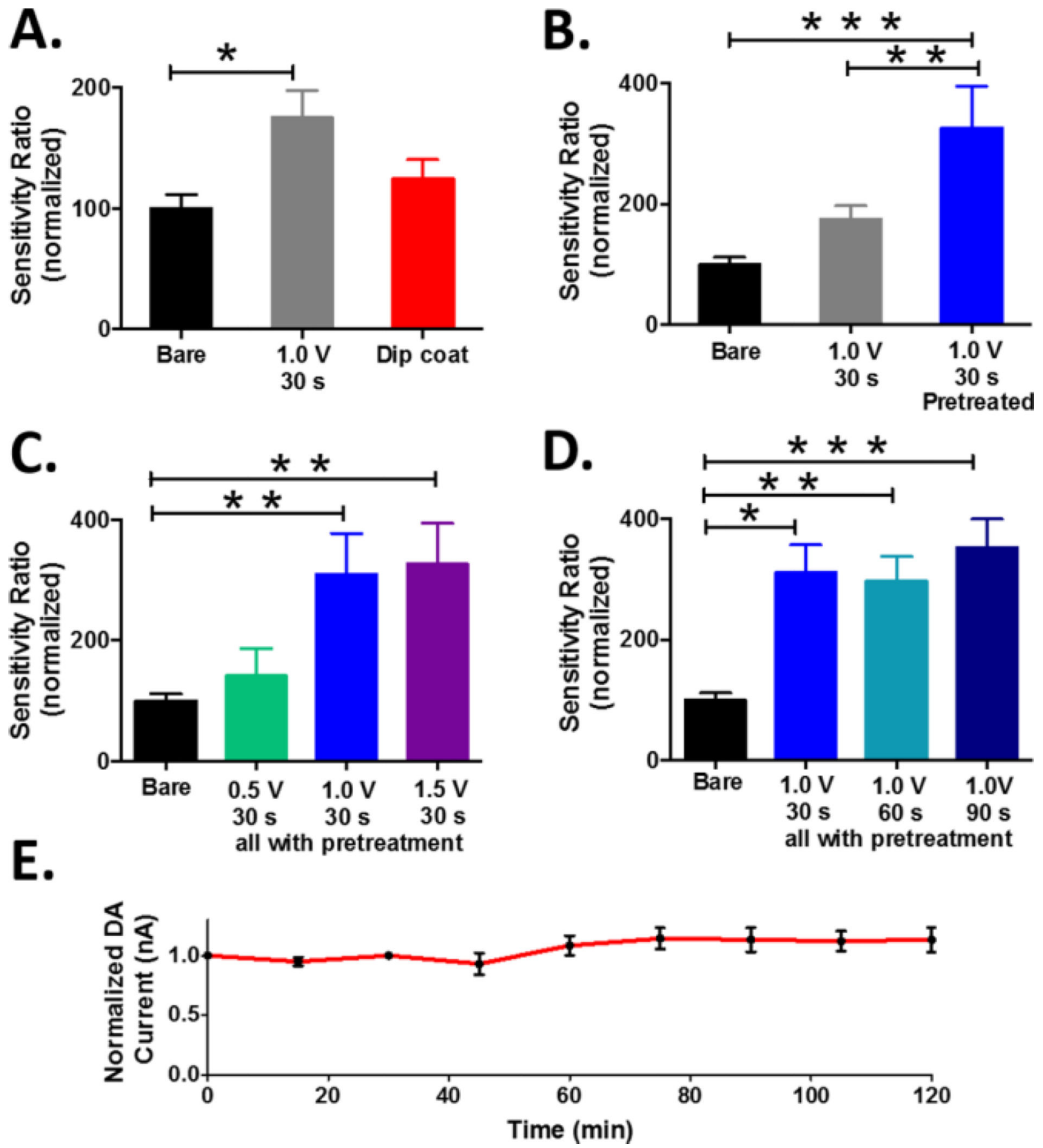

Figure 4.

Systematic characterization of Nafion coating procedures. (A) Dip coating versus electrodeposition $(\mathrm{F}(2,40)=4.76, * \mathrm{p}<0.05)$, (B) Electrochemical pretreatment before (blue) vs. after (gray) Nafion electrodeposition $(\mathrm{F}(2,36)=12.20, * * \mathrm{p}<0.01, * * * \mathrm{p}<0.001),(\mathrm{C})$ Electrodeposition potentials $(\mathrm{F}(3,33)=7.78, * * \mathrm{p}<0.01)$, (D) Electrodeposition times $(\mathrm{F}(3,51)=8.30, * \mathrm{p}<0.05, * * \mathrm{p}<0.01, * * * \mathrm{p}<0.001)$, (E) Stability of coated electrodes. In panels A-D, data are presented as normalized DA sensitivity ratio $(n=6-17$ electrodes per protocol, one way ANOVA with Tukey's post-hoc test, * $\mathrm{p}<0.05 ; * * \mathrm{p}<0.01 ; * * * \mathrm{p}<0.001$ ). 

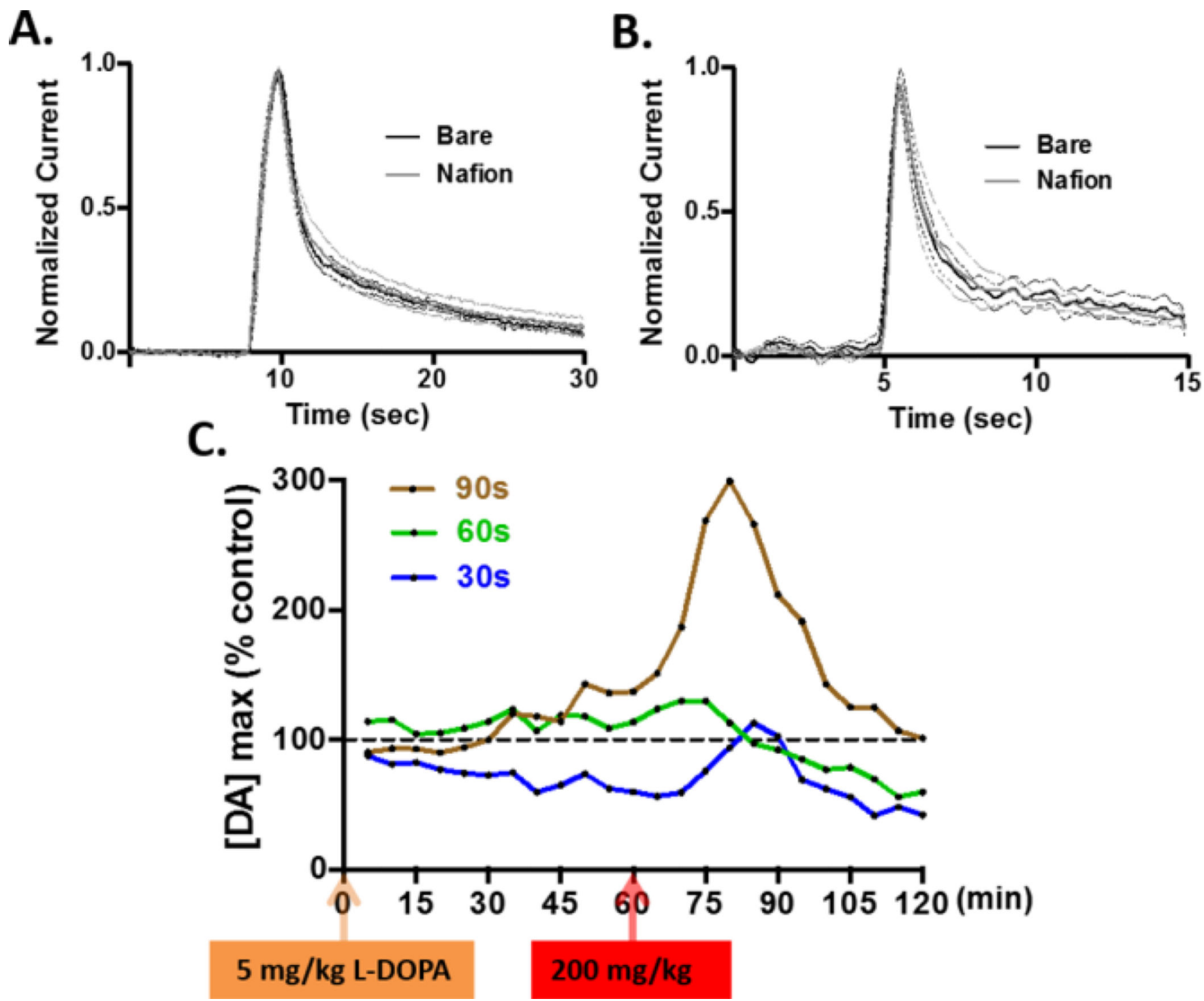

Figure 5.

DA concentrations recorded at Nafion coated electrodes. The optimized Nafion membrane (90 s electrodeposition time) did not affect the sub-second response time of the electrode when it was used (A) to record bolus injections of $500 \mathrm{nM}$ DA in a flow cell, or (B) to record electrically evoked DA release in rat striatum. In both (A) and (B), the mean current (solid) \pm SEM (dashed) is plotted for $\mathrm{n}=6$ electrodes. (C) Electrical stimulation was used to evoke striatal DA release every 5 minutes after L-DOPA administration. The $\mathrm{x}$-axis shows the 2- $\mathrm{h}$ window of data collection. The y-axis represents the normalized amplitude of electrically evoked DA release collected using electrodes that were electrodeposited with Nafion for 30 (blue), 60 (green), or 90 (brown) seconds. Arrows indicate the time at which L-DOPA was administrated (orange: $5 \mathrm{mg} / \mathrm{kg}$, red: $200 \mathrm{mg} / \mathrm{kg}$ ). 

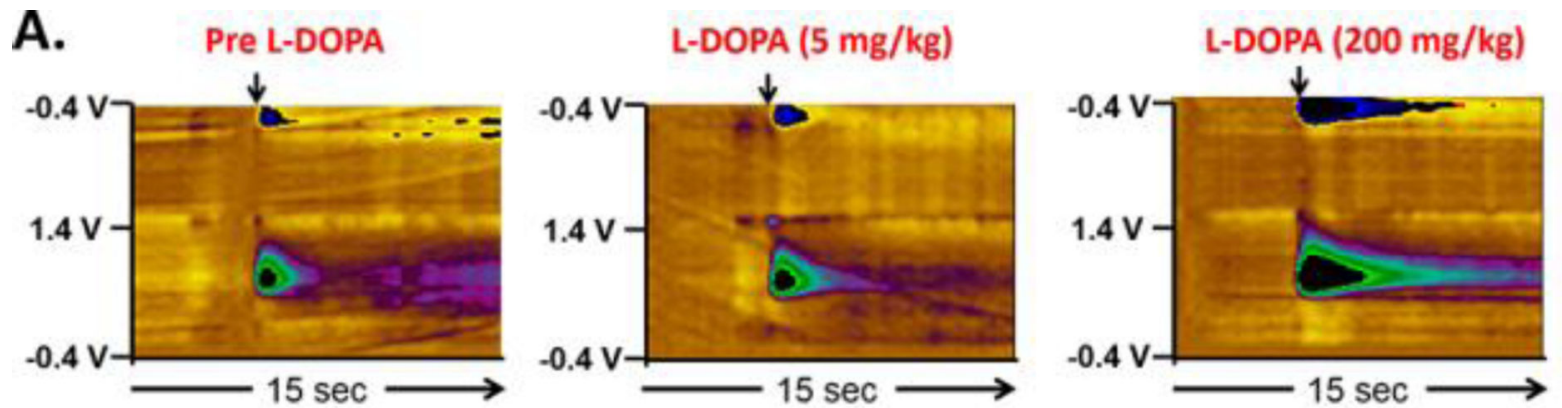

$-3.0 \mathrm{nA}$
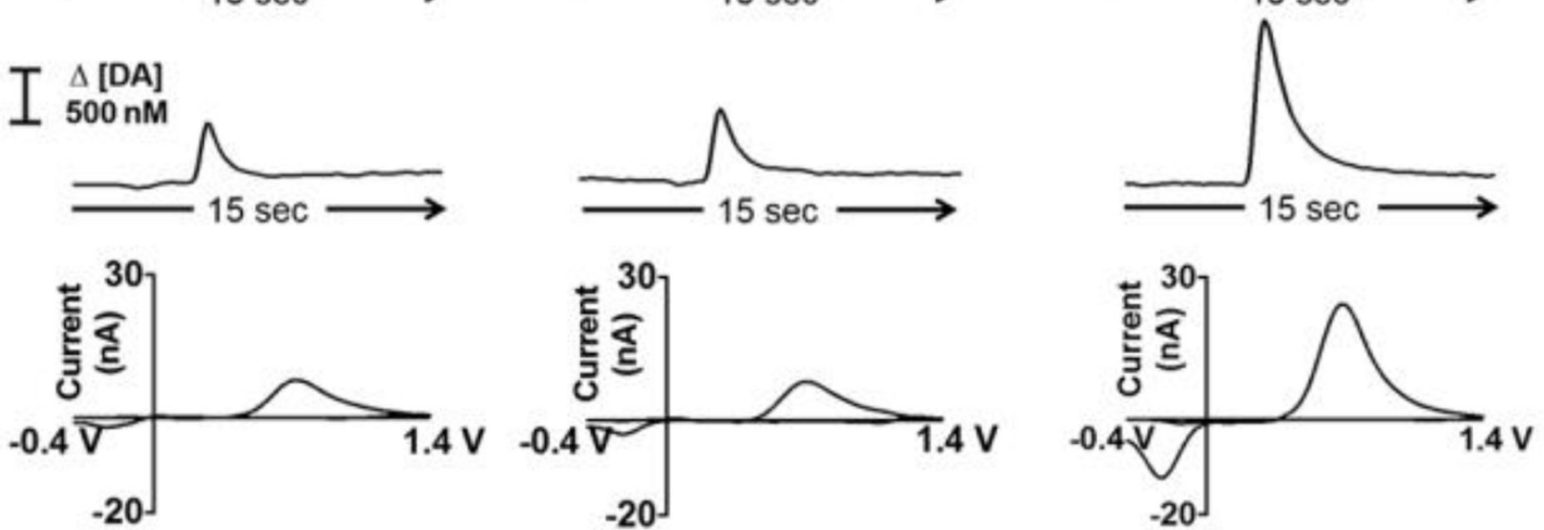

B.

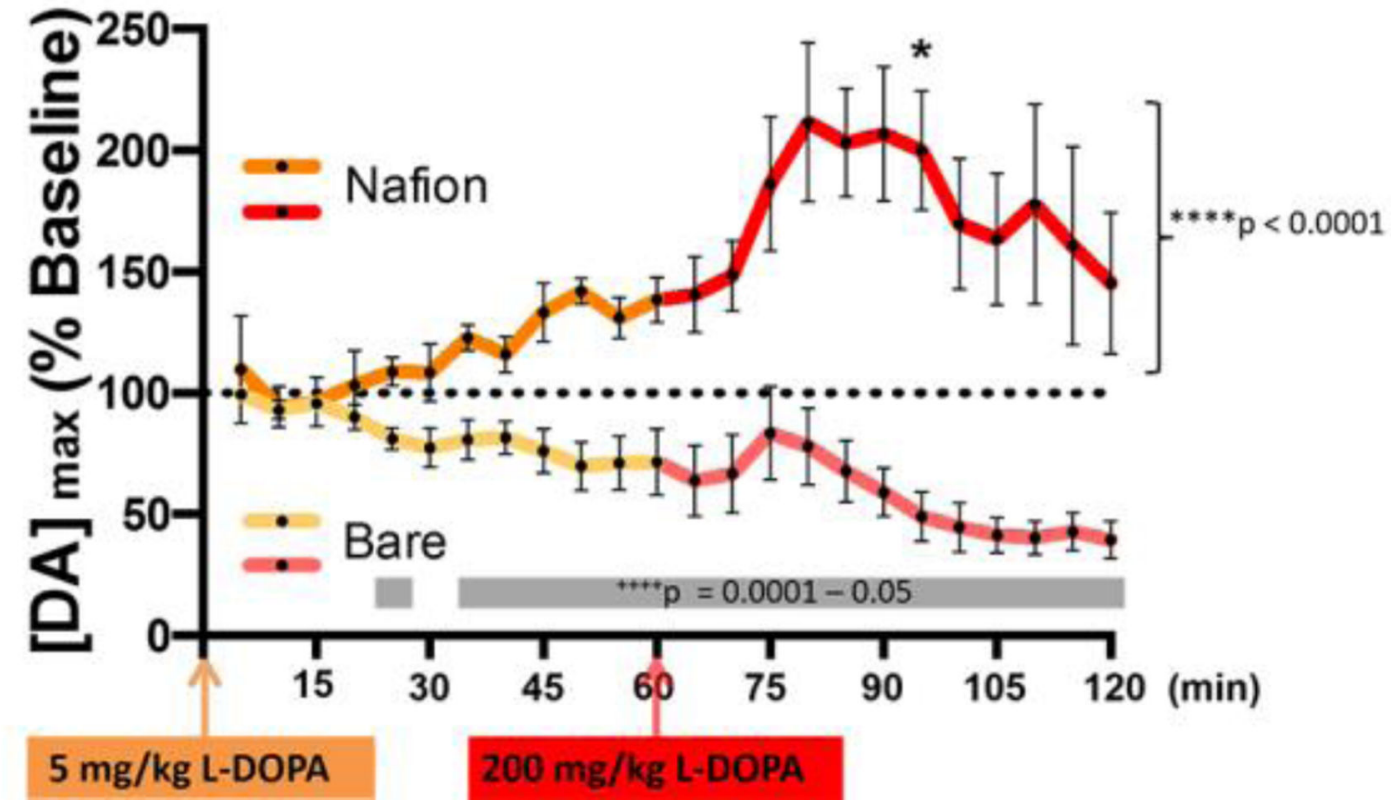

Figure 6.

The optimized Nafion membrane reveals that L-DOPA administration increases electrically evoked DA release. (A) Representative data collected at a Nafion-coated carbon-fiber microelectrode in an intact animal before L-DOPA administration (left column), $20 \mathrm{~min}$ after administration of L-DOPA (5mg/kg i.p., middle), and $20 \mathrm{~min}$ after administration of a higher dose of L-DOPA ( $200 \mathrm{mg} / \mathrm{kg}$ i.p., right). (B) When using Nafion-coated electrodes for the measurements, L-DOPA administration increased the amplitude of electrically evoked DA release overall $(\mathrm{n}=4$, bright orange and red trace, $\mathrm{F}(23,69)=2.880$, ****p < 
0.00001, one-way repeated measures ANOVA). Post-hoc analysis with a paired samples ttest demonstrated a significant increase 25 minutes after administration of $200 \mathrm{mg} / \mathrm{kg} \mathrm{L}$ DOPA $(* \mathrm{p}<0.05)$. Data collected using bare electrodes are also shown $(\mathrm{n}=5$, light orange and red trace) to enable direct statistical comparison of electrode performance in vivo. The differences between the two data sets are significant at several time points (gray boxes, repeated measures two-way ANOVA, all main and interaction effects, F(1-23, 7-161) = $\left.2.196-54.432,{ }^{++++} \mathrm{p}=0.00001-0.05\right)$. 
<smiles>[NH3+]CCc1ccc(O)c(O)c1</smiles><smiles>NCCC1=CC(=O)C(=O)C=C1[O+]</smiles>

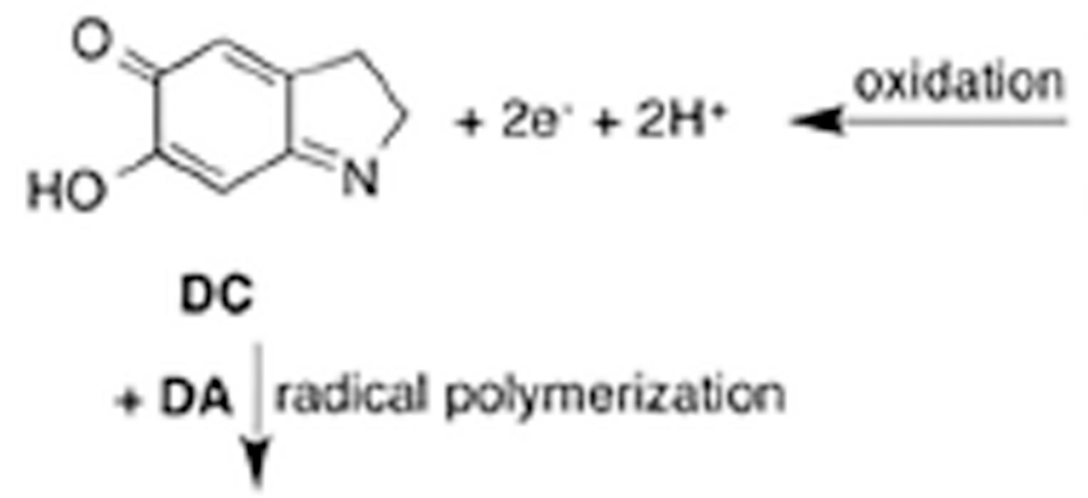
DC<smiles>CC(C)SS(O)(=S)=S</smiles><smiles>[CH+][C@H]1Cc2cc(O)c(O)cc2N1</smiles>
LDC

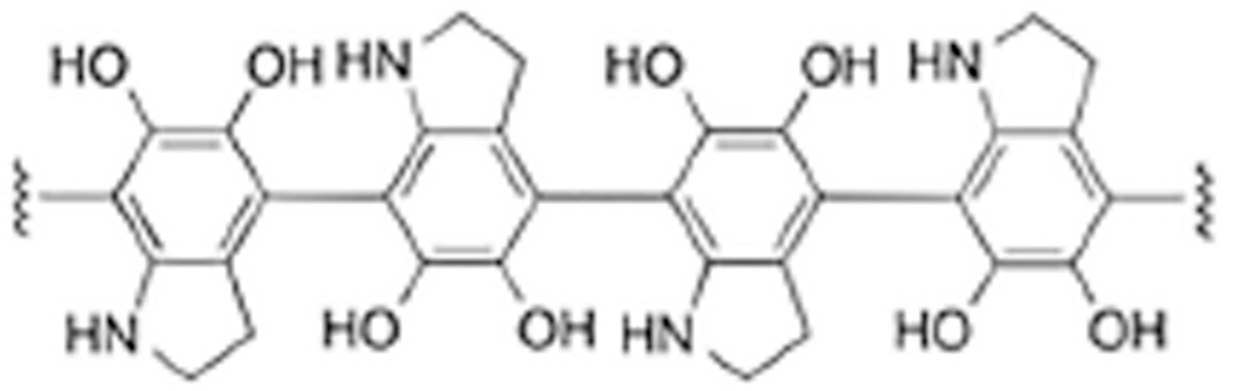

\section{Melanin}

Scheme 1.

DA polymerization pathway. 